\title{
Contribution of Rho-kinase and Adenosine Monophosphate-Activated Protein Kinase Signaling Pathways to Endothelium-Derived Contracting Factors Responses
}

\author{
Endotel Kaynaklı Kastırıcı Faktör Yanıtlarına Rho-kinaz ve Adenosin \\ Monofosfatla Aktive Edilmiş Protein Kinaz Sinyal Yolaklarının Katkısı
}

Cennet BALCILAR*, Işı ÖZAKCA, Vecdi Melih ALTAN

Ankara University, Faculty of Pharmacy, Department of Pharmacology, Ankara, Turkey

\begin{abstract}
Vascular tonus is controlled by endothelium-derived relaxing factor (EDRF), endothelium-derived hyperpolarizing factor (EDHF) and endotheliumderived contracting factor (EDCF) under physiological circumstances. In pathological conditions, impairment of endothelium-derived relaxation can be caused by both decrease in EDRF release and increase in EDCF release. The increase in EDCF is observed with diseases such as hypertension and diabetes. The contribution of Rho-kinase and activated protein kinase (AMPK), which have opposite effects, to the increased EDCF responses was investigated. Rho-kinases are the effectors of Rho which is one of the small guanosine triphosphate-binding proteins. They increase cytosolic $\mathrm{Ca}^{+2}$ concentration and cause vascular smooth muscle to contract, keeping myosin light chain (MLC) in phosphorylated state by affecting myosin phosphatase target subunit which dephosphorylates the MLC. The activities of Rho-kinases increase with the increase of EDCF function. AMPK is the energy sensor of the cell. It provides a vasculoprotective effect by causing endothelium-dependent and endothelium-independent relaxation in smooth muscle. In contrast to Rho-kinase pathway activity, AMPK pathway activity decreases with diseases in which the EDCF function increases. In cases such as diabetes and hypertension that endothelial function impairs toward vasocontraction, it is considered that evaluating Rho-kinase and AMPK pathways which mediate contraction and relaxation in vascular smooth muscle respectively, would provide clues on choosing therapeutic target for pathologies in which endothelial dysfunction is observed.
\end{abstract}

Key words: AMPK, EDCF, endothelium, Rho-kinaz

Öz

Fizyolojik koșullarda vasküler tonus endotel kaynaklı rahatlatıcı faktörü (EDRF), endotel kaynaklı hiperpolarizasyon faktörü (EDHF) ve endotel kaynaklı kasılma faktörü (EDCF) tarafından kontrol edilmektedir. Patolojik durumlarda endotel kaynaklı gevşemenin azalması, EDRF üretimindeki azalmaya bağlı olabileceği gibi EDCF düzeyinin artmasına da bağlı olabilmektedir. EDCF hipertansiyon, diyabet gibi hastalıklarda artmaktadır. Diyabet, hipertansiyon gibi patolojik koşullarda artan EDCF yanıtına birbirine ters etki yapan Rho-kinaz ve aktive protein kinaz (AMPK) yolaklarının katkısı olabileceği düşünülmektedir. Rho-kinazlar küçük guanozin trifosfat-bağlı proteinlerden biri olan Rho'nun efektörüdür. Rho-kinazlar hafif zincir miyozini (MLC) defosforile eden miyozin fosfataz hedef altbirimine etki ederek MLC'nin fosforile halde kalmasının sağlayarak sitozolik $\mathrm{Ca}^{+2}$ konsantrasyonu artırır ve vasküler düz kasın kasılmasına neden olurlar. Rho-kinazların aktivitesi EDCF yanıtlarının arttığı hipertansiyon, kalp yetmezliği ve diyabet gibi hastalıklarda artmaktadır. AMPK ise hücrenin enerji sensörü olarak düșünülmektedir. Vasküler düz kasta endotel bağımlı ve bağımsız gevşemeyi sağlayarak vasküloprotektif etki sağlamaktadır. AMPK'nin aktivitesi Rho-kinaz yolağının aktivitesinin tersine EDCF fonksiyonunun arttığı hipertansiyon ve diyabet gibi hastalıklarda azalmaktadır. Endotel fonksiyonunun vazokonstriksiyon yönünde bozulduğu diyabet, hipertansiyon gibi tablolarda, damar düz kas dokusunda sırasıyla kasılma ve gevșemeye aracılık eden Rho-kinaz ve AMPK yolaklarının birlikte değerlendirilmesinin, endotel fonksiyon bozukluğunun gözlendiği patolojilerde terapötik hedef seçiminde ipuçları sağlayabileceği düşünülmektedir. Anahtar kelimeler: AMPK, EDCF, endotel, Rho-kinaz 


\section{INTRODUCTION}

Under the normal physiological conditions, vascular tonus is controlled by endothelium-derived relaxation factors (EDRF) including nitric oxide (NO), endothelium-derived hyperpolarizing factor (EDHF) endothelium-derived contractile factor (EDCF).,2 The changes in these factors cause a change in the blood pressure. It is hypothesized that, the reduction of the endothelium-derived relaxation response in type II diabetes can be the result of the decrease EDRF production, as well as the increase of the EDCF level. ${ }^{3}$

\section{Endothelium-derived relaxation factors}

In 1980, Furchgott and Zawadzki ${ }^{4}$, for the first time, proved that the endothelial cells are necessary for the relaxation of the vascular tissue via acetylcholine $(\mathrm{ACH})$ and that the relaxation of the vascular muscle is provided via the secretion of the EDRF from endothelium. The neurotransmitters, hormones, and as a response to mechanical stress, the EDRF and/or EDCF can be secreted from the endothelial cells. ${ }^{5}$ EDRF includes NO and prostaglandin $\mathrm{I}_{2}$ [prostacyclin $\left(\mathrm{PGI}_{2}\right){ }^{6}{ }^{6}$ EDRF induces the relaxation of the vascular smooth muscle via the activation of $\mathrm{K}^{+}$channels. $\mathrm{PGI}_{2}$ and $\mathrm{NO}$ mediate the relaxation with the increase of the concentrations of the seconder messengers, such as cyclic adenosine monophosphate (AMP) and cyclic guanosine monophosphate inside the cell. ${ }^{5}$

\section{Endothelium-derived hyperpolarizing factor}

In addition to EDRF, EDHF also mediates the relaxation of the smooth muscle. ${ }^{7}$ Although the molecular mechanism of the vasorelaxing activity of the EDHF has not been completely understood, it is thought that the mechanism is achieved via the occurence of the hyperpolarization as a result of the opening of the $\mathrm{K}^{+}$channels. ${ }^{7}$ EDHF is defined as the endothelium-mediated relaxation response, which is observed after the $\mathrm{PGI}_{2}-\mathrm{NO}$ block is made. ${ }^{7}$

\section{Endothelium-derived contractile factor}

Endothelium-derived contraction happens via the cyclooxygenase (COX) products. ${ }^{3}$ The COX's convert the arachidonic acid into endoperoxides. Endoperoxides, on the other hand, with the help of the appropriate enzymes are converted to various prostaglandins, such as, $E_{2}\left(P G E_{2}\right)$ prostaglandin $D_{2}\left(P G D_{2}\right)$, prostaglandin $F_{2 \alpha}\left(P G F_{2 \alpha}\right)$, and $P G I_{2}$ tromboxan $A_{2}\left(T \times A_{2}\right)$. These prostanoids create the EDCF response by activating the thromboxane-prostanoid (TP), a receptor which is locked to the G-protein in smooth muscle. This contraction response occurs as a result of the increase of the amount of the $\mathrm{Ca}^{+2}$ ions entering the smooth muscle cells, which is achieved via the opening of the receptor-mediated and voltage dependent $\mathrm{Ca}^{+2}$ channels. ${ }^{9}$ Under in vitro conditions the removal of the EDCF responses are removed via: (i) the incubation made with the COX inhibitors, which inturn results in the inhibition of the prostanoid production in endothelium and (ii) the incubation made with the antagonists of the TP receptors, which prevents the excitation of these receptors via prostanoids. ${ }^{10}$ These results prove that the COX products and TP receptors are responsible from the EDCF-mediated response. ${ }^{10}$
EDCF response can be triggered by the $\mathrm{ACH}$ which excites the endothelium $\mathrm{M}_{3}$ - muscarinic receptors, and by vasoactive agonists like adenosine diphosphate, which activates purinergic receptors. ${ }^{9}$ Just like these vasoactive agonists, $\mathrm{Ca}^{+2}$ ionophore A23187, an agent which increases the entrance of $\mathrm{Ca}^{+2}$ also triggers the creation of EDCF response. These agents are used for the evaluation of EDCF response, experimentally, under in vitro conditions (Figure 1).

The TP receptors belong to the family of the receptors locked to the Gq-protein. The endothelium-derived contraction responses created via the activation of TP receptors are associated with the increase of the sensitivity to Rho-kinase (ROCK)-mediated myofilaments. ${ }^{10}$

\section{Rho-kinase pathway}

The guanosine triphosphate (GTP)-locked proteins mediate the inside-cell pathways of the membrane receptors. These GTPlocked proteins include the Rho, Ras, Rab, Sarl/Arf and Ran families. ${ }^{11}$ In the mammals, the RhoA, RhoB, RhoC, RhoD, RhoE and RhoG izoforms of the Rho family are defined. ${ }^{12}$ RhoA is the most famous member of the Rho protein family. It participates in the organization of the actin, contraction, motility, proliferation and apoptosis. ${ }^{12}$ In order for the RhoA-mediated cell response to occur, it plays the key role as the ROCK downstream effector in the interaction of inactive GDP and active GTP. ${ }^{12}$ RhoA is activated via the conversion of guanine nucleotide from GDP to GTP. The proteins activating the GTP-ase excite the intrinsic GTP-ase activity, whereas they deactivate the RhoA. ROCK are the first and most important effectors of the RhoA.13,14 There are two isoforms of ROCK, namely, ROCK1 and ROCK2.14 Although

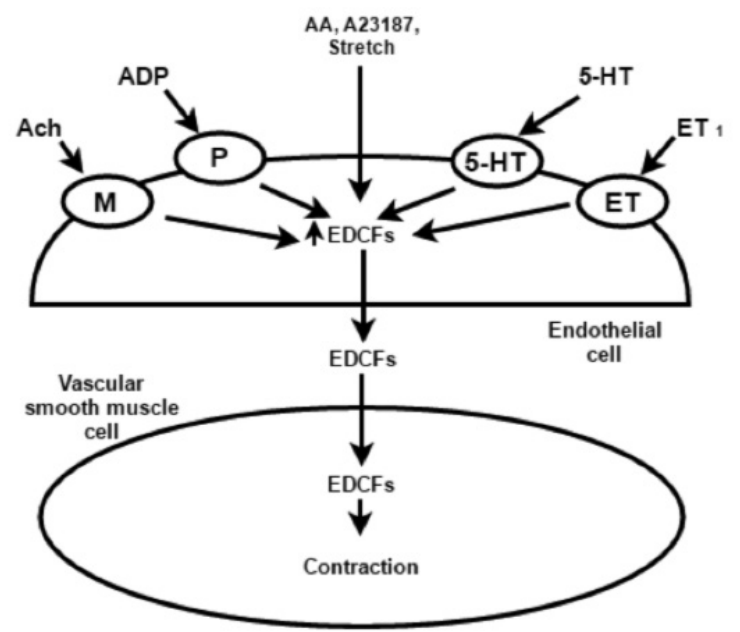

Figure 1. The creation and effect mechanism of endothelium-derived contractile factor, As a result of the bonding of some neuromediators to their corresponding receptors in endothelium cells, production of a $\mathrm{Ca}^{+2}$ ionophore A23187, arachidonic acid and an increase of the endotheliumderived contractile factor production occurs, which then results in the contraction of the smooth muscle ${ }^{9}$

Ach: Acetylcholine, ADP: Adenosine diphosphate, AA: Arachidonic acid, ET: Endothelin M: Muscarinic receptor, P: Purinergic receptor, 5-HT: 5-hydroxytryptamine, EDCF: Endothelium-derived contractile factor 
these two isoforms are located with different concentrations at different tissues, no functional difference between them has been defined. ${ }^{15}$ The activity of the RhoA/Rho associated protein kinase pathway is increased in diabetes, as well as it is occurred in hypertension, coroner vasospasm, stroke, atherosclerosis and heart failure. ${ }^{16}$ This situation makes the ROCK a new and important theurapeutic aim. ${ }^{16}$

The targets of ROCK, such as myosin phosphatase target subunit (MYPT-1), myosin light chain (MLC) and calponin play the key role in the contraction of the smooth muscle cells. MYPT-1 is the major effector in the contraction of the smooth muscle for the ROCK associated $\mathrm{Ca}^{+2}$ sensitivity. ${ }^{10}$ In addition, MLC, C-kinase potentiated protein phosphatase-1 inhibitor (CPI17) and the phosphorylation of the calponin contribute to the ROCK associated smooth muscle contraction. In the vascular smooth muscle, the MLC is phosphorylated by the MLC kinase, (MLCK) which is activated by $\mathrm{Ca}^{+2}$-calmoduline-dependent kinase, and dephosphorylated by the $\mathrm{Ca}^{+2}$-independent MLC phosphatase (MLCP). ${ }^{13,14}$ The MLC, which gets phosphorylated with the activation of the MLCK, mediates the increase of the cytosolic $\mathrm{Ca}^{+2}$ concentration and the vascular smooth muscle contraction occurs (Figure 2). ${ }^{12}$

ROCK inhibits the production of NO from the endothelium cells. The activation of RhoA/ROCK decreases the endotelial NO synthase (eNOS) expression by inhibiting the eNOS mRNA stability. ${ }^{13}$ It was shown that the eNOS expression increases during the treatment of human umbilical vein endothelial cells channel via the incubation of ROCK inhibitor Y27632 (10 $\mu \mathrm{mol} / \mathrm{L}){ }^{17}$ Among the ROCK inhibitors, only the fasudil is approved for the clinical use in the cerebral vasospasm endication. ${ }^{18}$ In addition to fasudil, Y-27632 is another ROCK inhibitor whose activity is also proven and which has been used in several studies. ${ }^{18}$

There are several studies demonstrating that the ROCK pathway activity increases in parallel to the EDCF response. For instance, in the spontaneously hypertensive rats the inhibitors of the ROCK inhibit the increasing EDCF response in the carotid arter, under in vitro conditions, ${ }^{10}$ and in STZ-diabetic rats the application of fasudil treatment $(5 \mathrm{mg} / \mathrm{kg} /$ day, oral) for a period of 16 weeks decreases the vascular contraction response..$^{19}$

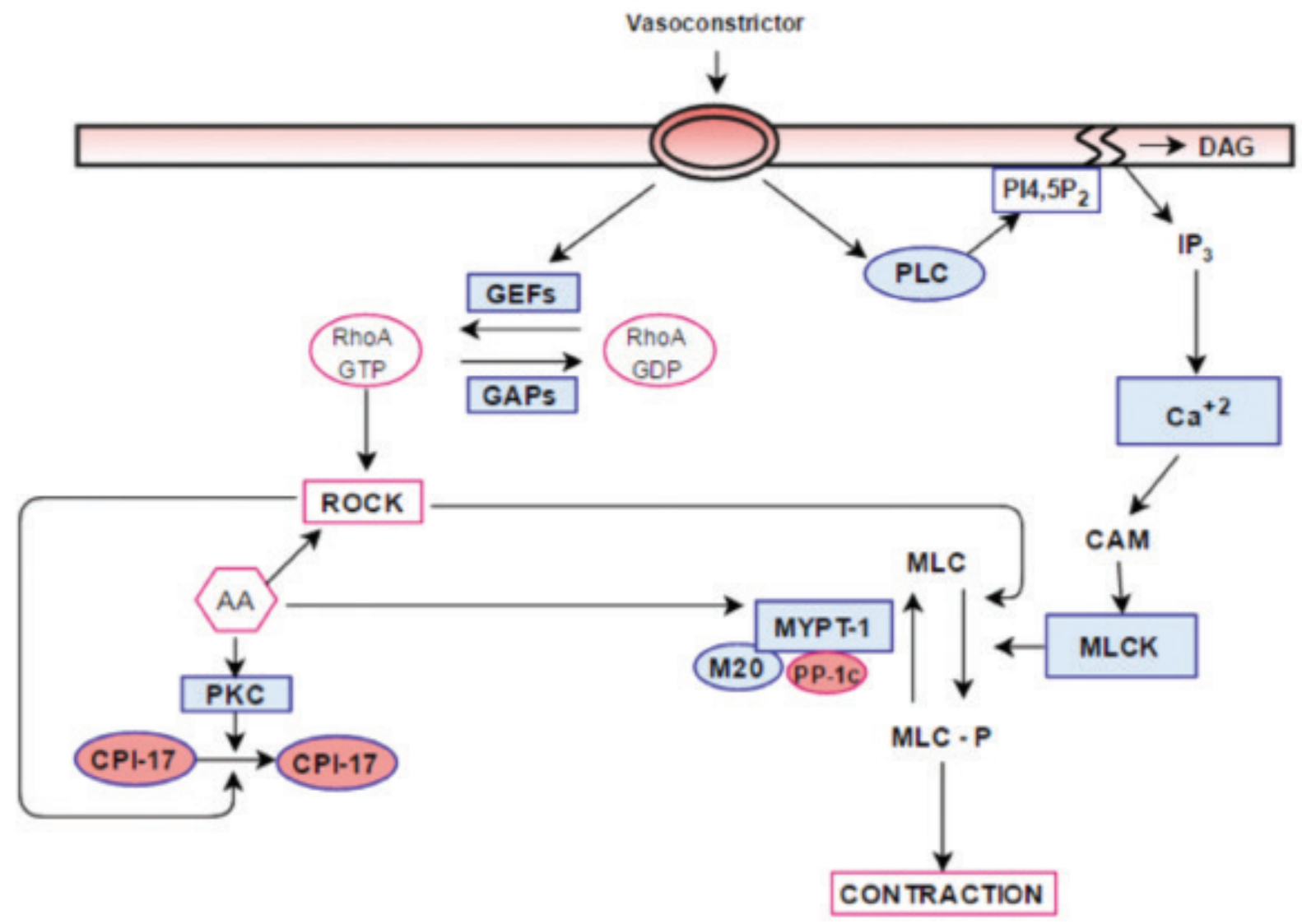

Figure 2. The contraction signal mechanism of the vascular smooth muscle cells, The contraction is induced by an increase of $20-\mathrm{kDa}$ in myosin light chain phosphorylation, Excitation of the receptor locked to the G protein, by the vasoconstrictor agent increases the $\mathrm{Ca}^{+2}$ concentration in the cell, thereby inhibiting the myosin light chain phospatase, via the excitation of the myosin light chain kinase, myosin light chain phospatase consists of 3 parts, These subunits are the catalytic subunit PP-1c, myosin phosphatase target-1 and 20-kDa subunit M20, Vasoconstrictor increases the the agent induced myosin light chain phospatase inhibition and activation of RhoA and Rho-kinase ${ }^{12}$

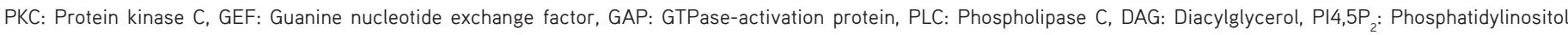

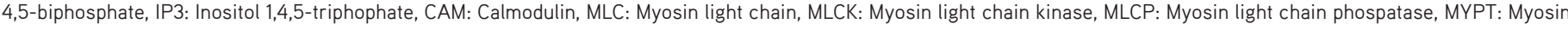
phosphatase target, ROCK: Rho-kinases, AA: Arachidonic acid, GTP: Guanosine triphosphate 


\section{Adenosine monophosphate-activated protein kinase pathway}

Another pathway which is hypothesized to be related to EDCF is adenosine monophosphate-activated protein kinase (AMPK). AMPK term was introduced in 1988, by Sim and $\mathrm{Hardie}^{20}$, for the first time. Being a serine/threonine kinase AMPK regulates all of the cellular events and is though as the energy sensor of the cell. 21,22

AMPK consists of 3 subunits, namely, $\alpha, \beta$ and $\gamma$. $\alpha$ and $\beta$ subunits consist of 2 isoforms, whereas $\gamma$ subunit has 3 isoforms. ${ }^{22}$ These isoforms have different placements in different tissues at different expression levels. Each isoform is coded by a different genes. $\alpha$ is the catalytic subunit; whereas, $\beta$ and $\gamma$ are regulatory subunits. $\alpha$ subunit consists of a autoinhibitor region, which inhibits the catalytic kinase region of $\mathrm{N}$ terminal, and the activity of the $C$ terminal when the regulatory part AMP is not present, and a region which is connected to the $\beta$, and $\gamma$ subunits. $\alpha_{1}$ subunit is dominant at adipose tissue, in the pancreas island cells, at endothelium and vascular smooth muscle, $\alpha_{2}$ subunit on the other hand is dominant in skeletal and heart muscles. $\beta$ subunit works as a sketelon which connects the $\alpha$ and $\gamma$ subunits. $\gamma$ subunit, on the other hand, carries the connection parts of AMP and adenosine triphosphate (ATP). ${ }^{21}$

The activity of AMPK increases in the situations where the need of ATP increases; such situations are exercise, hunger, inflammation and hypoxia. AMPK effects the metabolisms of lipid, carbohydrate, and proteins. Activation of AMPK regulates the lipid methabolism by ensuring the fat oxidation, producing the cholesterol in liver, decreasing the synthesis of the fatty acids and increasing the lipolysis in adipocytes. The effect of AMPK on carbohydrate metabolism can be summarized as the increase of the glucose uptake in the skeleton muscle and at heart, with the activation of AMPK, the excitation of glucogeneogenesis enzym in the liver and the regulation of the insulin secretion of the $\beta$ cells in pancreas. In addition to these effects, the activation of AMPK increases the NO production at heart and vascular endothelium. Long periods of AMPK activation might cause modifications in protein synthesis via the modulation of transcription factors, like myocyte enhancer factor-2, mammalian target of rapamycin and eukaryotic elongation factor $2 .^{23}$

Antidiabetic agents, such as, metformin ${ }^{24}$, thiazolidinediones, glukagon like peptid-1 agonists, dipeptidyl peptidase-4 inhibitors, statins, adiponectin and the leptin hormone increase the AMPK activation. ${ }^{25,26}$ Experimentally, 5-aminoimidazole-4carboxamide ribonucleoside is used for the AMPK activation ${ }^{24}$, whereas the dorsomorphine (compound $\mathrm{C}$ ) is used for the inhibition.

AMPK increases the eNOS activity in the smooth muscle, which in turn increases the NO-mediated endothelium-dependent relaxation. The endothelium independent relaxation, on the other hand, is ensured by AMPK via the decrease in the $\mathrm{Ca}^{+2}$ sensitivity of the MLCK in the smooth muscle cell (Figure 3). It therefore shows a vasoprotective effect. ${ }^{25-27}$ It is thought that the vasoprotective effects of the therapeutic agents like, metformin ${ }^{24}$, thiazolidinediones and statins also occur via the AMPK activation. ${ }^{21}$ AMPK activation causes the NO-mediated

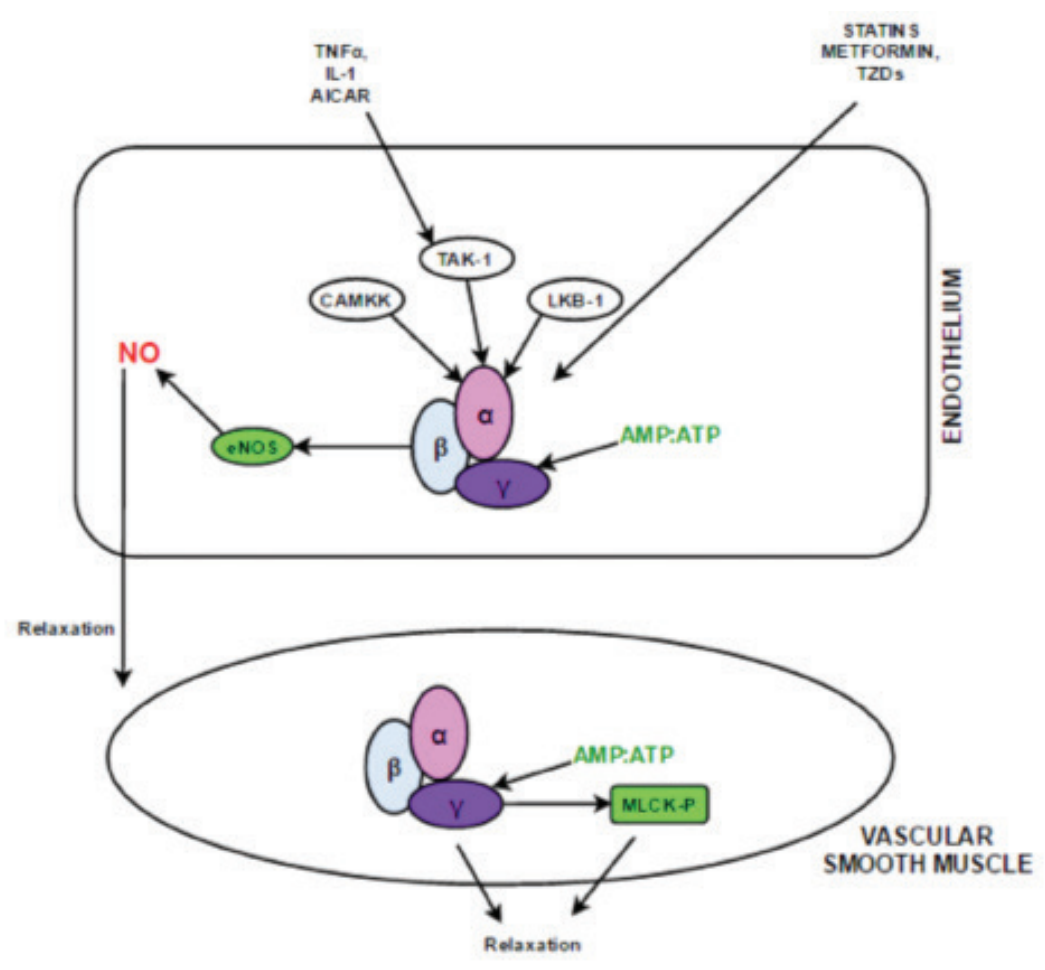

Figure 3. The vascular effect of the AMPK activation and the agents activating AMPK ${ }^{21}$

TNF- $\alpha$ : Tumor necrosis factor-alpha, IL: Interleukin, AICAR: 5-aminoimidazole-4-carboxyamide-1- $\beta$-D-ribofuranoside, CAMKK: Calmodulin-dependent kinase kinase, TAK: Transforming growth factor $\beta$-activated kinase, LKB: Liver kinase B, MLCK: Myosin light chain kinase, AMP: Adenosine monophosphate, ATP: Adenosine triphosphate, NO: Nitric oxide 
relaxation in the spontaneously hypertensive rats. ${ }^{25-28}$ AMPK, at the same time, causes the endothelium independent vascular smooth muscle relaxation in the aort preparations of the Mouse. $^{27}$

\section{Rho-kinase and adenosine monophosphate-activated protein kinase interaction}

In the pathologies with hyperglycemia and hypertension, the inverse effects of AMPK and ROCK pathways results in the speculations that these two pathways are related to each other.

Increase in ROCK activation suppresses production of $\mathrm{NO}$ in endothelium cells and indirectly causes contraction in vascular smooth muscle. This is related with ROCK activation's effects of decreasing eNOS expression and mRNA stability. ROCKs effect on MYPT-1 also plays role in this pathway. By keeping MYPT1 inactive, ROCK triggers MLC phosphorylation, cytosolic $\mathrm{Ca}^{+2}$ level increase and as a result it's contraction. ${ }^{13}$ AMPKs vascular effect is the opposite of this. In contrast to ROCKs effect, AMPK activation increases the activity of eNOS in arterial smooth muscle. It causes endothelium dependent relaxation by increasing the production of NO. On the other hand, it causes endothelium independent relaxation by decreasing intracellular $\mathrm{Ca}^{+2}$ sensitivity and vascular tonus through activating MLCK in vascular smooth muscle cell. ${ }^{25-27}$ In summary, ROCK activation makes hypertension and diabetes like pathologies more critical by causing increase in vascular contraction. Increase in the AMPK activation, can help fixing vascular complications caused by these pathologies with its vasculoprotective effect. From this point of view, it is believed that in pathologies in which vascular tonus increases, inhibition of ROCK activity and activation of AMPK can be beneficial. That is why ROCK inhibitors and agents that are increasing the activation of AMPK are considered as new therapeutic targets. ${ }^{18-25}$

ROCK and AMPK is related also because the molecules below are up-regulated ROCK inhibition. And these molecules are the downstream targets of AMPK (Figure 4) ${ }^{29}$ :

Cpt1a and Cpt1b that play role in obtaining energy through lipolysis and carrying fatty acids from outer membrane of mitochondria to cytosol, Cycs (cytochrome C) and Cox4i1 (cytochrome $\mathrm{C}$ oxidase lower unit 4i1), transmembrane proteins in mitochondria and last receiver of the electron transfer chain, Slc2a4, glucose transporter which is found in muscle tissue and adipose tissue.

Additionally, it is another finding that shows the relationship between these pathways that, as a ROCK inhibitor hydroxyfasudil increase the NAD+/NADH rate and Sirtuin-1 activity (Figure 4) which are AMPK's downstream target. ${ }^{29}$

In experimental models and humans, observing metformin, which causes AMPK activation, decrease body weight and serum lipid levels like fasudil does, is another sign of the interaction. $^{29}$

Below studies are made in order to enlighten the relationship between AMPK and ROCK pathways:

In hypertensive rats that angiotensin are induced, it is observed that resveratrol treatment stabilizes the blood pressure by decreasing ROCK activity and AMPK activation. ${ }^{30}$

Metabolic disorders observed in rats that are fed with high fat diet, are fixed with ROCK inhibitor and AMPK mediated.

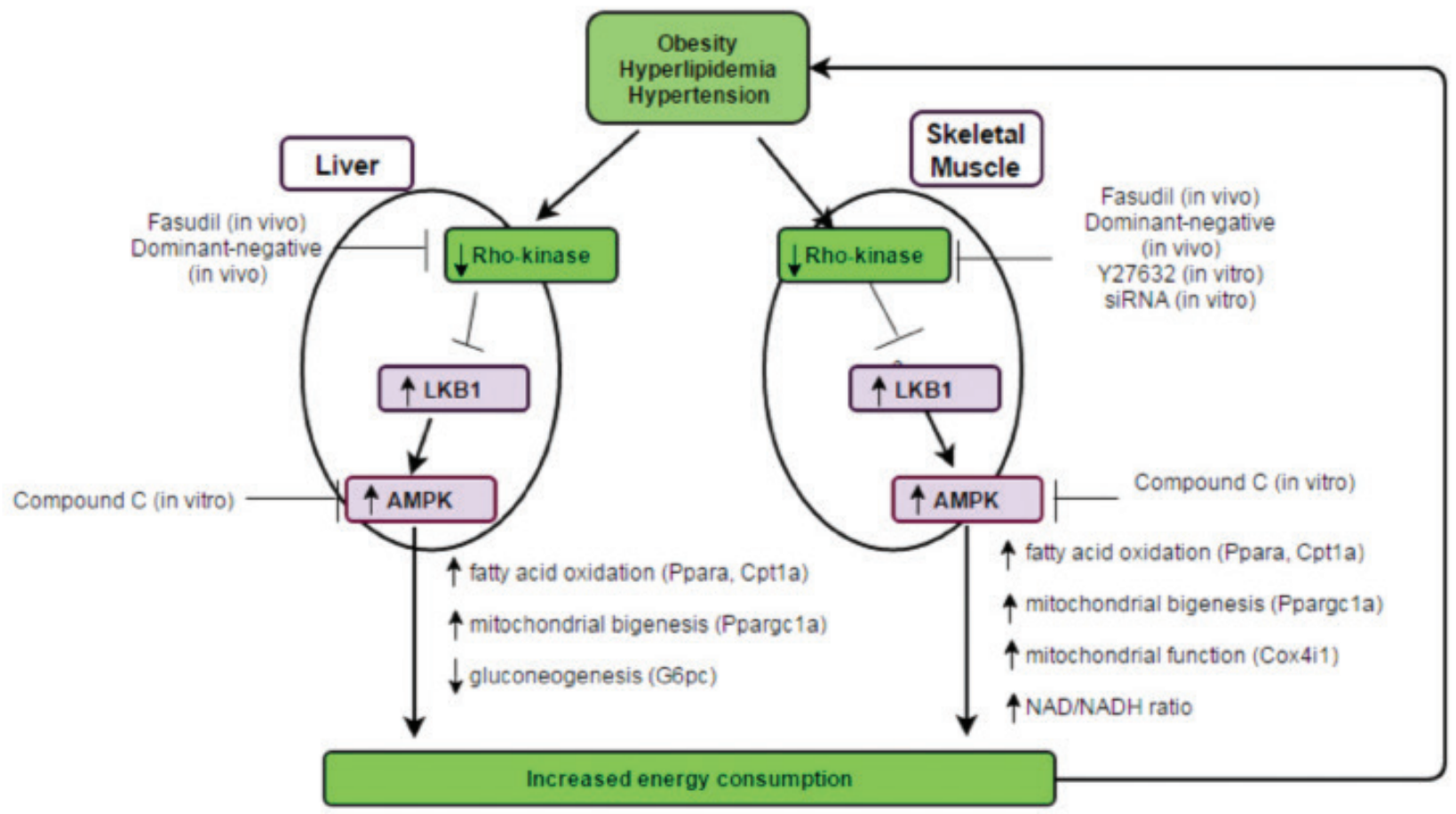

Figure 4. Rho-kinase inhibition increases energy consumption by activating AMPK $\alpha 2$ through liver kinase B-1, effect of change in Rho-kinase activity on adenosine monophosphate-activated protein kinase activity ${ }^{29}$ 
And positive effects of the treatment with ROCK inhibitor are disappeared in rats AMPK gene is deleted. ${ }^{29}$

\section{DISCUSSION}

In pathologies that endothelium functions impair, ROCK activity increases in parallel with EDCF response while AMPK pathway activity decreases. It is thought that, having these pathways response to the same pathologies adversely might mean that there is a relationship between them. It is seen as a sign of relationship between pathways in following researches: hypertensive rats with induced angiotensin, it is observed that resveratrol treatment stabilizes the blood pressure by decreasing ROCK activity and AMPK activation ${ }^{30}$, metabolic disorders observed in rats that are fed with high fat diet, are fixed with ROCK inhibitor and AMPK mediated. And positive effects of the treatment with ROCK inhibitor are disappeared in AMPK gene deleted rats. ${ }^{29}$ ROCK activation makes hypertension and diabetes like pathologies more critical by causing increase in vascular contraction. Increase in AMPK activation contributes recovery of vascular complications related with these pathologies by providing a vasculoprotective effect. That is why, in pathologies with vascular tonus increase, it is thought that ROCK activity inhibition and AMPK activity activation might be beneficial. Hence, ROCK inhibitors and AMPK activating agents are considered as new therapeutic targets. ${ }^{18-25}$ Evaluating ROCK and AMPK pathways together can provide hints about therapeutic target selection in the pathologies in which endothelium function impairs.

Conflict of Interest: No conflict of interest was declared by the authors.

\section{REFERENCES}

1. Feletou M, Vanhoutte PM. Endothelial dysfunction: a multifaceted disorder (The Wiggers Award Lecture). Am J Physiol Heart Circ Physiol. 2006;291:9851002.

2. Pieper GM. Review of alterations in endothelial nitric oxide production in diabetes: protective role of arginine on endothelial dysfunction. Hypertension. 1998; 31:1047-1060.

3. Matsumoto T, Kobayashi T, Kamata K. A therapeutic target for microvascular complications in diabetes: endothelium-derived hyperpolarizing factor. Curr Cardiol Rev. 2006;2:185-191.

4. Furchgott RF, Zawadzki JV. The obligatory role of endothelial cells in the relaxation of arterial smooth muscle by acethylcholine. Nature. 1980;288:373376.

5. Shen B, Ye CL, Ye KH, Liu JJ. Mechanism underlying enhanced endotheliumdependent vasodilatation in thoracic aorta of early stage streptozotocininduced diabetic mice. Acta Pharmacol Sin. 2003;24:422-428.

6. Kang KT. Endothelium-derived relaxing factors of small resistance arteries in hypertension. Toxicol Res. 2014;30:141-148.

7. Ohashi J, Sawada A, Nakajima S, Noda K, Takaki A, Shimokawa H. Mechanism for enhanced endothelium-derived hyperpolarizing factor-mediated responses in microvessels in mice. Circ J. 2012;76:1768-1779.

8. Vanhoutte PM. Vascular biology. Old-timer makes a comeback. Nature. 1998;396:213-216.

9. Vanhoutte PM, Feletou M, Taddei S. Endothelium-dependent conractions in hypertension. Br J Pharmacol. 2005;144:449-458.

10. Denniss SG, Jeffery AJ, Rush JW. RhoA-Rho kinase signaling mediates endothelium and endoperoxide dependent contractile activities characteristic of hypertensive vascular dysfunction. Am J Physiol Heart Circ Physiol. 2010;298:1391-1405.

11. Shinmokawa $\mathrm{H}$, Takeshita A. Rho-kinase is an important therapeutic target in cardiovascular medicine. Arterioscler Thromb Vascl Biol. 2005;25:1767-1775.

12. Loirand G, Guèrin $P$, Pacaud $P$. Rho kinases in cardiovascular physiology and pathophysiology. Circ Res. 2006;98:322-334.

13. Loirand G. Rho Kinases in Health and Disease: From Basic Science to Translational Research. Pharmacol Rev. 2015;67:1074-1095.

14. Shimokawa H, Sunamura S, Satoh K. RhoA/Rho-Kinase in the Cardiovascular System. Circ Res. 2016;118:352-366.

15. Hahmann C, Schroeter T. Rho-kinase inhibitors as therapeutics: from pan inhibition to isoform selectivity. Cell Mol Life Sci. 2010;67:171-177.

16. Zhou H, Li YJ. Rho kinase inhibitors: potential treatments for diabetes and diabetic complications. Curr Pharm Des. 2012;18:2964-2973.

17. Eto M, Barandier C, Rathgeb L, Kozai T, Joch H, Yang Z, Lüscher TF. Thrombin suppresses endothelial nitric oxide synthase and upregulates endothelinconverting enzyme-1 expression by distinct pathways: role of Rho/ROCK and mitogen-activated protein kinase. Circ Res. 2001;89:583-590.

18. Surma M, Wei L, Shi J. Rho kinase as a therapeutic target in cardiovascular disease. Future Cardiol. 2011;7:657-671.

19. Li T, Yang GM, Zhu Y, Wu Y, Chen XY, Lan D, Tian KL, Liu LM. Diabetes and hyperlipidemia induce dysfunction of VSMCs: contribution of the metabolic inflammation/miRNA pathway. Am J Physiol Endocrinol Metab. 2015;308:257269.

20. Sim AT, Hardie DG. The low activity of acetyl-CoA carboxylase in basal and glucagon-stimulated hepatocytes is due to phosphorylation by the AMPactivated protein kinase and not cyclic AMP-dependent protein kinase. FEBS Lett. 1988;233:294-298.

21. Ewart MA, Kennedy S. AMPK and vasculoprotection. Pharmacol Ther. 2011;131:242-253.

22. Li J, Li S, Wang F, Xin F. Structural and biochemical insight into the allosteric activation mechanism of AMP-activated protein kinase. Chem Biol Drug Des. 2016:1-7.

23. Hardie DG, Alessi DR. LKB1 and AMPK and the cancer-metabolism link - ten years after. BMC Biol. 2013;15:11-36.

24. Yan T, Zhang J, Tang D, Zhang X, Jiang X, Zhao L, Zhang Q, Zhang D, Huang Y. Hypoxia Regulates mTORC1-Mediated Keratinocyte Motility and Migration via the AMPK pathway. Plos One. 2017;12:e0169155.

25. Ford RJ, Rush JW. Endothelium-dependent vasorelaxation to the AMPK activator AICAR is enhanced in aorta from hypertensive rats and is NO and EDCF dependent. Am J Physiol Heart Circ Physiol. 2011;300:64-65.

26. Batchuluun B, Inoguchi T, Sonoda N, Sasaki S, Inoue T, Fujimura Y, Miura $D$, Takayanagi R. Metformin and liraglutide ameliorate high glucose-induced oxidative stress via inhibition of PKC-NAD(P)H oxidase pathway in human aortic endothelial cells. Atherosclerosis. 2014;232:156-164.

27. Goirand F, Solar M, Athea Y, Viollet B, Mateo P, Fortin D, Leclerc J, Hoerter J, Ventura-Clapier R, Garnier A. Activation of AMP kinase alpha1 subunit induces aortic vasorelaxation in mice. J Physiol. 2007;581:1163-1171.

28. Ford RJ, Teschke SR, Reid EB, Durham KK, Kroetsch JT, Rush JW. AMPactivated protein kinase activator AICAR acutely lowers blood pressure and relaxes isolated resistance arteries of hypertensive rats. J Hypertens. 2012;30:725-733.

29. Noda K, Nakajima S, Godo S, Saito H, Ikeda S, Shimizu T, Enkhjargal B, Fukumoto Y, Tsukita S, Yamada T, Katagiri H, Shimokawa H. Rho-kinase inhibition ameliorates metabolic disorders through activation of AMPK pathway in mice. Plos One. 2014;9:e110446.

30. Cao X, Luo T, Luo X, Tang Z. Resveratrol prevents Angll-induced hypertension via AMPK activation and RhoA/ROCK suppression in mice. Hypertens Res. 2014;37:803-810. 